\title{
Methamphetamine, Neurotransmitters and Neurodevelopment
}

\author{
Barbora ČECHOVÁ ${ }^{1}$, Romana ŠLAMBEROVÁ ${ }^{1}$ \\ ${ }^{1}$ Department of Physiology, Third Faculty of Medicine, Charles University, Prague, Czech Republic
}

Received July 13, 2021

Accepted October 14, 2021

\begin{abstract}
Summary
Methamphetamine (MA), as massively abused psychoactive stimulant, has been associated with many neurological diseases. It has various potent and neurotoxic properties. There are many mechanisms of action that contribute to its neurotoxic and degenerative effects, including excessive neurotransmitter (NEU) release, blockage of NEU uptake transporters, degeneration of NEU receptors, process of oxidative stress etc. MA intoxication is caused by blood-brain barrier disruption resulted from MA-induced oxidation stress. In our laboratory we constantly work on animal research of MA. Our current interest is to investigate processes of MA-induced alteration in neurotransmission, especially during development of laboratory rat. This review will describe current understanding in role of NEUs, which are affected by MA-induced neurotoxicity caused by altering the action of NEUs in the central nervous system (CNS). It also briefly brings information about NEUs development in critical periods of development.
\end{abstract}

\section{Key words}

Methamphetamine • Neurotransmitters • Addiction • Substance abuse disorder • Oxidative stress • Behavior alteration • Limbic system • Basal ganglia

\section{Corresponding author}

R. Šlamberová, Department of Physiology, Third Faculty of Medicine, Charles University, Ke Karlovu 4, 12000 Prague, Czech Republic. E-mail: romana.slamberova@If3.cuni.cz

\section{Introduction}

This review builds on our previous articles summarizing knowledge of the effect of methamphetamine (MA) on an individual's prenatal and early postnatal development. Our previous reviews were about the long-term effects of MA on the mother and her offspring (Slamberova 2019) with respect to the detailed description of the anatomical structures involved (Tomášková et al. 2020), and possible sensitizing effect of prenatal MA exposure (Macuchova and Slamberova 2016) This review deepens the knowledge about the mechanism of action of MA, especially with regard to NEU systems and their development.

\section{Methamphetamine}

MA is well known active psychostimulant widely abused around the world that belongs to amphetamines chemical group. In 1887, amphetamine was synthesized by the German chemist Lazar Edeleano. Later in 1893 and 1919, MA was synthesized from ephedrine by the Japanese pharmacologist Nagayoshi Nagai and the chemist Akira Ogata (Anglin et al. 2000, Grella and Anglin 2009). This central nervous system (CNS) stimulant usually called meth, crystal, or speed can be injected, smoked, snorted, or ingested orally. Prolonged use at high levels causes strong dependence (Anglin et al. 2000). MA gained its popularity thanks to very quick onset of desirable effects, such include euphoria, alertness, wakefulness etc. MA also has anorectic effect that can represent one of the reasons of its popularity. However, with many desirable effects, there comes the dark side with it that has negative impact on human well-being. MA usually causes hypertension, hyperthermia, excitation and most importantly behavioral alterations. Behavioral alterations include motor and psychiatric effects such as hyperlocomotion, addiction, craving, aggressiveness, psychosis, depression, cognitive impairments, and altered cortical excitability like sleep alterations (Vrajova et al. 2021). Excessive MA using can 
produce long-lasting alterations, which may be the consequence of neurotoxicity or being produced by epigenetic changes in some brain areas (Anglin et al. 2000).

MA addiction is caused by long-lasting neuronal adaptations which render reward and motivation brain systems hypersensitive to drug and drug-associated stimuli. Repeated administration of MA causes a behavioral sensitization, which besides addiction includes behavioral abnormalities such as drug craving, relapse, and psychotic episodes. MA chemical structure is similar to ephedrine. Chronic abuse of MA leads to cognitive dysfunction mostly by significant changes in distribution and storage of brain monoamine NEUs, such as dopamine (DA) and noradrenaline (NA), thanks to MA's chemical structure similarity to these two NEUs (Fig. 1). MA also alters neurotransmission of serotonin (5-HT) and other NEUs like glutamate (GLU) and gamma-aminobutyric acid (GABA). Mechanisms of action of MA thought all above mentioned neurotransmissions are somehow linked together (Hedges et al. 2012, Hedges et al. 2018, Ferrucci et al. 2019).<smiles>NCCc1ccc(O)c(O)c1</smiles><smiles>CC(N)CC1=CC=CCC1</smiles><smiles>CCCCON(C)O[Na]</smiles><smiles>CNC(C)Cc1ccccc1</smiles>

Fig. 1. Demonstration of amphetamine and MA's chemical structure and its similarity to monoamine neurotransmitters. MA differs from amphetamine by presence of methyl group. Picture taken from Hart et al. (2012).

\section{Neurotransmitters}

NEUs are substances that mediate chemical signaling between neurons. There are three types of NEUs: small-molecule transmitters, peptides, and gaseous transmitters. The small molecule NEUs may be further subdivided into acetylcholine, amino acids, biogenic amines, and purines. The first three groups of small-molecule transmitters contain what are the classic NEUs. For purpose of this review, we are going to focus on two most important amino acid NEUs and monoamines. NEUs play an important role in the development of nervous systems critical windows of the development. Development is characterized by timing and spacing or critical periods when some kind of stimulation is essential for correct development (Diamond et al. 2004, Breen et al. 2016).

The expression of NEU type seems to be dependent on a tissue factor and also can be affected by other factors such as corticosteroids. Environmental factors are important for the differentiation of certain neuronal cells and can have a critical role during critical stages of development (Albers and Sonsalla 1995, Chebib and Johnston 1999, Chebib and Johnston 2000, Diamond et al. 2004).

\section{GABA, GLU and their role in MA-induced neurotoxicity}

GLU is the amino acid NEU at the majority of excitatory synapses in CNS. It is present in all cells and it has a key role in multiple metabolic pathways, and it is a precursor to GABA, the major inhibitory NEU. As being the main excitatory NEU, GLU is a potent neurotoxin at high concentrations. Because of this fact, limitation of GLU's activity after its release from the presynaptic terminal is necessary. It is not only to allow normal synaptic transmission but also to prevent cell death. GLU has both ionotropic and metabotropic receptors. Based on pharmacological properties a subunit composition, several distinct ionotropic receptor subtypes are recognized for example $\alpha$-Amino-3-hydroxy-5methyl-4-isoxazolepropionic acid (AMPA) receptors, and $\mathrm{N}$-methyl D-aspartate (NMDA) receptors. Release of the GLU from presynaptic densities activates postsynaptic GLU-gated ion channels including AMPA receptors, NMDA and kainate (KA) receptors. Once activated, the GLU-gated ion channels flux $\mathrm{Na}^{+}$and in some cases will also flux $\mathrm{Ca}^{2+}$. NMDA receptors are uniformly $\mathrm{Ca}^{2+}$-permeable, with well-recognized roles in synaptic 
plasticity and disease (Stephans and Yamamoto 1994). Most AMPA receptors and some KA receptors are $\mathrm{Ca}^{2+}$-impermeable, however $\mathrm{Ca}^{2+}$-permeable AMPA receptors and KA receptors also exist at some synapses where they can play a role in synaptic plasticity and disease. AMPA receptors behave as classic ligandgated channels on binding of GLU to the receptor, the channel opens and allows current to flow. NMDA channels are different because they require binding of both GLU and glycine to open and display voltage sensitivity as a result of blockade of the channel. Interesting feature of NMDA channels is that they are generally permeable to $\mathrm{Ca}^{2+}$, which can act as second messenger. The combination of voltage sensitivity and $\mathrm{Ca}^{2+}$ permeability of the NMDA channels creates hypothesis about their role in learning and memoryrelated functions (Mark et al. 2004).

Acute administration of MA increases levels of GLU in the striatum and the prefrontal cortex via a polysynaptic process, where the increased DA release activates GABA neurons in the striatum of the direct pathway and increases GABA release at their terminals in the substantia nigra pars reticulata $(\mathrm{SNr})$. Pre-synaptic $D_{1}$ receptors on the striatonigral terminals also enhance GABA release at the SNr. The increased GABA at the substantia nigra cell bodies disinhibit the thalamocortical GLUergic pathway, which results in an increase of GLU within the cortex. High levels of GLU at the level of the cortex activates the GLUergic corticostriatal neurons via topographically specific postsynaptic density connections, and increases GLU release in the striatum, driving positive feedback. GLU levels in the striatum in fact remain elevated for over $28 \mathrm{~h}$, even after DA has returned to basal levels. It was found that the vesicular GLU transporter 1 expression was increased, which allows for the sequestration of GLU in the cortex, and thus allowing extended GLU release into the striatum after MA administration. The NMDA receptors in the striatum facilitate $D_{1}$ receptor mediated currents, which positively drives this circuit (Schmidt et al. 1985, Zhou and Palmiter 1995, Boyson and Adams 1997).

Endogenous GLU within the nucleus accumbens regulates MA reward during withdrawal confirm the functional relevance of a MA-induced hyper-GLUergic state for addiction-related behavior. Nucleus accumbens GLUergic consequences of repeated MA exposure are very distinct from those produced by repeated exposure of other substances. There is a hypothesis that the hypoGLUergic state reported in a rat model of MA relapse reflects neuroadaptations induced by extinction learning, rather than a pharmacodynamic response to the drug itself (Sulzer et al. 2005, Hsieh et al. 2014, Szumlinski et al. 2017).

GABA is the major inhibitory transmitter throughout the nervous system. GABA is produced from GLU by a specific enzyme that is present only in neurons that use GABA as a NEU (Chebib et al. 1998, Chebib and Johnston 1999, Chebib and Johnston 2000). GABAergic synapses make up the majority of inhibitory synapses in the brain. GABA has ionotropic receptors that are members of the Cys-loop family, sharing a number of characteristics, as already described. In addition, each of these receptors has a $\mathrm{Cl}^{-}$channel, which opens while the portion is bound. Different subunits of receptors confer distinct properties on the receptor. The ionotropic GABA A receptors are the major inhibitory NEU receptors that mediate fast synaptic transmission inhibitory effects. The GABA A $\alpha 1 \beta 2 \gamma 2$ receptor subtype combination is the most abundant subtype in most brain areas. GABAergic signaling in DAergic brain areas, like the VTA and the substantia nigra pars compacta, is also mainly mediated by the GABAA $\alpha 1 \beta 2 \gamma 2$ receptor subtypes. The GABA B receptors are G-protein-coupled receptors with seven transmembrane domains. The two subunits of a GABA B receptor are GABA B1. Binding of GABA to receptor GABA B activates a heterotrimeric GTP-binding protein, which leads to activation of $\mathrm{K}^{+}$channels and hyperpolarization of the postsynaptic cell, as well as inhibition of $\mathrm{Ca}^{2+}$ channels and a reduction in release of transmitter (Chebib et al. 1998, Chebib and Johnston 1999, Chebib and Johnston 2000, Wearne and Cornish 2019).

MA acts primarily through basal ganglia and limbic system, which are creating the reward path and control movement. Striatum as part of basal ganglia consist of GABAergic projection neurons that express NMDA receptors. The striatonigral neurons are characterized by the expression of D1 receptors, project to the basal ganglia output nuclei, SNr, internal globus pallidus, the starting point of the direct pathway. The striatopallidal neurons, characterized by the expression of D2 receptors, project to the globus pallidus externa, and begin the indirect pathway. Increased DA release activates GABA neurons in the striatum of the direct pathway and increases GABA release at their terminals in the substantia nigra. The increased GABA at the $\mathrm{SNr}$ cell bodies disinhibit the thalamocortical GLUergic pathway, which results in an increase of GLU within the cortex. 
The high levels of GLU at the level of the cortex activates the GLUergic corticostriatal neurons via topographically specific postsynaptic density connections, and increases GLU release in the striatum, driving positive feedback (Chebib and Johnston 1999, Meldrum 2000, Bennett et al. 2007, Pereira et al. 2008).

Acute MA administration has been found to decrease GABA B transmission within the ventral tegmental area (VTA), and increases DA release from the VTA to the nucleus accumbens. This release of DA in the mesolimbic pathway is associated with the experience of reward or euphoria, and increases subsequent GABA release to the substantia nigra for longer than $80 \mathrm{~min}$. Inhibition of the $\mathrm{SNr}$ disinhibits the thalamocortical GLUergic pathway, and results in increased cortical GLU. High-dose injections of MA (40 mg/kg) over seven continuous days could activate the apoptotic cascade of mouse striatal GABAergic neurons and induced $45 \%$ apoptosis of the parvalbumin-positive neurons in the striatum (Chebib and Johnston 1999, Meldrum 2000, Szumlinski et al. 2017). See Table 1 for most used protocols of experimental MA administration.

GLU levels in the striatum in fact remain elevated for several hours, even after DA has returned to basal levels. It was found that the vesicular GLU transporter 1 expression was increased, which allows for the sequestration of GLU in the cortex, and thus allowing extended GLU release into the striatum after MA administration. The NMDA receptors in the striatum facilitate D1 receptor mediated currents, which positively drives this circuit. Since the $\mathrm{SNr}$ GABAergic neurons are tonically active there is normally little movement at rest, or minimal signaling to the cortex from the thalamus. Cortical GLUergic activation of either the direct or indirect pathway primes the relevant pathway to an "upstate". Activation of the DA system enhances GLU signaling in the cortex from the nigrostriatal and mesolimbic pathways, and increases DA in the prefrontal cortex from the mesocortical pathway (Koob and Le Moal 2001, Pereira et al. 2008, Hsieh et al. 2014, Szumlinski et al. 2017).

\section{Role and development of monoamine NEUs in MA's mechanism of action}

Monoamine neuron cell bodies are located in the brainstem and the hypothalamus, with their axons projecting throughout the brain and spinal cord. Monoaminergic neurons function in important processes, including emotion, arousal, mood, reward, sleep, and memory, despite the fact they represent very small number of neurons in the brain. Therapeutic drugs that modulate monoamine transmission are used to treat depression, bipolar disorder, attention deficit hyperactivity disorder, anxiety disorders, posttraumatic stress disorder, schizophrenia, and Parkinson disease. Several addictive drugs of abuse, such as MA, lead to alteration of neuronal circuits involving monoamines. All monoamines function via specific metabotropic G-protein-coupled receptors however, 5-HT also use an ionotropic receptor. Given their mechanisms of action through $G$ proteins and second messenger pathways, monoamines function in slow synaptic transmission and neuromodulation (Herlenius and Lagercrantz 2001, Chugani 2002, Fleckenstein et al. 2009, Hedges et al. 2018).

The levels of most NEUs and neuromodulators increase with formation of synapses. Some of them surge during the perinatal period. Monoamines are expressed in the early embryonal stage, at which the notochord already contains high NA levels. In the adult mammals, there is domination of excitatory neurotransmitters, such as GLU, that seem to be important wiring of the brain and the plasticity before birth. NMDA receptors dominate, while mediating these effects, and are then substituted by AMPA receptors. GABA is excitatory in the developing brain by depolarizing developing neurons that have high $\mathrm{Cl}^{-}$concentrations. This seems to be of major importance for the wiring of neuronal circuits. Prenatal or neonatal stress, e.g. hypoxia, can affect the programming of NEU and receptor expression, which can lead to long-term behavioral effects (Diamond 1996, Naqui et al. 1999, Herlenius and Lagercrantz 2001, Herlenius and Lagercrantz 2004) (Fig. 5).

The monoamine NEUs transporters - DAT, 5-HTT, NAT play an important role in controlling the signal amplitude and duration of monoaminergic neurotransmission by altering the concentration of monoamines in the extracellular space of the CNS. Therefore, direct or indirect modulation of these transporters can significantly affect the regulation of neuronal activity. There are the primary targets of action of a number of psychostimulants and drugs of abuse such as MA and many more which are blocking or reversing the transport of NEUs and increase the synaptic neurotransmission leading to stimulation (Aggarwal and Mortensen 2017).

All three monoamine transporters are distributed 
throughout the brain, and due to their extensive distributions in the brain, they control a wide variety of physiological and behavioral functions. In the CNS, they are expressed in their corresponding monoaminergic neurons that have projections mainly throughout the neocortex, basal ganglia and limbic forebrain areas. These monoaminergic projections interact with and innervate other neurons in the brain. DAergic neurons that express DAT project from the VTA and substantia nigra to pre-frontal cortex, nucleus accumbens and striatum (Shao and Zhu 2020). These projections control functions such as memory, planning, attention, motivation, reward and reinforcement processes, and movement. 5-HTT is expressed in the serotonergic neurons that project from raphe nuclei of pons and upper brain stem to hypothalamus, thalamus, amygdala, striatum, etc. These neurons regulate mood, emotion, learning, cognition, memory, sleep, and appetite. There are expressed in many peripheral sites such as the gut, lung, placenta, platelets, lymphocytes. NAT is expressed in noradrenergic neurons present in the locus coeruleus and the lateral tegmental group that innervate regions such as striatum, amygdala, hypothalamus, thalamus, cerebellum, brain stem, spinal cord, and cortex. These neurons control processes such as modulation of arousal, sleep-wake cycle, and cognition. Noradrenergic neurons also mediate the stress and fear-related response by controlling the endocrine and the autonomic nervous system (Goldstein 1998, Shao and Zhu 2020, Meyers et al. 2021).

\section{Noradrenaline and MA}

Noradrenergic neurons appear at an early stage in the CNS. 12-14 ${ }^{\text {th }}$ day in the rat and 5-6 weeks in the human (Naqui et al. 1999, Happe et al. 2004). NA is essential for normal brain development. The noradrenergic system regulates the development of the Cajal-Retzius cells that are the first neurons in the cortex. Lesioning the noradrenergic projections or blocking neurotransmission with receptor antagonist prevents astrogliosis and glial cell proliferation. Depleting NA during the perinatal period results in subtle dendritic changes and possibly also alterations in cortical differentiation. There is a critical window during early development when NA is involved in forming the pathways responsible for maternal behavior. NA is also involved in the olfactory learning of the newborn, which is of importance for maternal recognition (Olson and
Seiger 1972, Kuczenski et al. 1995, Naqui et al. 1999, Herlenius and Lagercrantz 2001).

System of the NA is generally neuroprotective and influences the vulnerability of nigrostriatal DA neurons. NATs expressed by NA neurons can take up MA and act as a buffer by sequestering MA and other toxins (Albers and Sonsalla 1995, Fumagalli et al. 1998, Hedges, Obray et al. 2018, Ferrucci et al. 2019). NA strongly modulates MA-induced behaviors and reward path that is the basis for behavior leading to addiction to MA and as one of the main NEUs that produce reward, NA nuclei contributes to the neurobiology of reward induced by MA. NA neurons are also involved in genetic susceptibility to MA-induced behavioral effects because genetic polymorphism affecting the limiting enzyme for NA synthesis, DA betahydroxylase, that is involved in substance abuse disorder (Chebib and Johnston 1999, Herlenius and Lagercrantz 2001, Herlenius and Lagercrantz 2004, Gupta and Kulhara 2007, Hedges et al. 2018).

\section{DA and parts of the reward pathway altered by MA}

Cell bodies of the DArgic neurons are concentrated in the substantia nigra, the VTA and project to the basal ganglia, the limbic regions, and the hippocampus and to the cortex. Particularly the prefrontal cortex is rich in DA content, and this part of brain has important role for reasoning, planning, problem solving in human. DArgic neurons appear early during development at the gestational age of 10-15 days in the rat and 6-8 weeks in the human, earlier in females than in males (Boyson and Adams 1997, Herlenius and Lagercrantz 2001).

The mesolimbic DA system, consisting of DArgic neurons projecting from the midbrain to target areas in the striatum and nucleus accumbens. It has been implicated in reward and motivation for drugs of abuse including MA. It is the most important reward pathway in brain. This circuit consisting of VTA and nucleus accumbens connection is a key detector of a rewarding stimulus. Under normal conditions, the circuit controls an individual's responses to natural rewards, such as food, sex, and social interactions, and is therefore an important determinant of motivation and incentive drive. Activation of the pathway tells the individual to repeat what it just did to get that reward. It also tells the memory centers in the brain to pay particular attention to all features of that 
rewarding experience, so it can be repeated in the future. It is a very old pathway from an evolutionary point of view. The use of DA neurons to mediate behavioral responses to natural rewards is seen in worms and flies, which evolved 1-2 billion years ago. VTA is primary source of DA to the nucleus accumbens and the ventral hippocampus. These three brain regions are functionally connected through the hippocampal-VTA loop (Calipari et al. 2016, Calipari et al. 2017).

Biochemical differentiation of DAergic neurons within the rat's mesencephalon occurs soon after their mitotic activity has ceased, but before they fully achieve morphological maturity. Neurons in the VTA undergo extensive alterations in their morphological features and soma size during the first two postnatal weeks. It has also been shown, that DAergic fibers enter cortical areas very early in life, but at least for the prefrontal and cingular cortex adult patterns of innervation are only achieved by the end of postnatal week 2 and 3 respectively, which coincides or follows the time when cells in the VTA were found here to exhibit mature morphological characteristics (Takada and Hattori 1987, Dinopoulos and Parnavelas 1991).

The formation of the hippocampus is generated during embryonic development, but most neurons within the structure are produced after birth. The hippocampus is a primary region of neurogenesis within the adult mammalian brain. Adult-born neurons have to integrate into the established neural circuitry throughout life. The hippocampus has two main histological divisions: Ammon's horn and the dentate gyrus. The primary neuronal cell layer of Ammon's horn is composed of glutamatergic excitatory pyramidal neurons. Pyramidal cells are born primarily prenatally with the peak of neurogenesis in the last week of gestation in rodents. The dendrites of CA3 pyramidal cells continue to mature postnatally with the formation of spines. The granule cells are the primary cell layer of the dentate gyrus and $85 \%$ are formed postnatally. There are two cellular migrations of granule cell precursors, originating from the secondary dentate matrix close to the neuroepithelium, that contribute to the development of the granular cell layer. The first dentate migration, completed prenatally, follows a subpial route and directly contributes cells to the growing granular cell layer. The second dentate migration stream is between the pyramidal cell layer and the forming growing granular cell layer. It gives rise to late-born granule cells, which migrate radially to the inner portion of the growing granular cell layer and the subgranular zone. Granule cells continue to be generated in the adult hippocampus and are a source of adult neural stem cells (Lagali et al. 2010).

The nucleus accumbens is a major component of the ventral striatum and has long been thought to be a key structure involved in mediating motivational and emotional processes, the limbic-motor interface, and the effects of many psychoactive drugs. It has been implicated in numerous neurological and psychiatric disorders, including depression, obsessive-compulsive disorder, bipolar disorder as well as in drug abuse and addiction. Neurons of nucleus accumbens are generated over a 50-day period beginning around embryonic day 36, with rodent studies noting that neurogenesis briefly continues postnatally. Development of primary neurons of nucleus accumbens can be influenced by environmental factors. Studies have demonstrated that both prenatal and postnatal stress in animals heightens the complexity of dendritic morphology of the nucleus accumbens, altering the branching, length, and spine density of the medium spiny neurons (Ali et al. 1995, Boyson and Adams 1997, Pereira et al. 2008, Hedges et al. 2018). See Figures 3 and 4 for illustrating the reward path of the human and rat brain affected by MA.

There are two main types of DA receptors - D1 and D2. Stimulation of the D1 receptors results in an increase in cAMP formation, while D2 receptors mediate a decrease in cAMP formation. D1 receptor stimulation regulates transcription of other genes, and it is possible that abnormal perinatal stimulation can result in longterm consequence. D1-receptors are involved in working memory performance. A disturbance of the development of the DArgic system has been postulated to contribute to the cause of Attention Deficit Hyperactivity Disorder (ADHD) in which a deficient working memory is an important component (Albers and Sonsalla 1995, Boyson and Adams 1997, Pendleton et al. 1998, Herlenius and Lagercrantz 2001, Ferrucci et al. 2019, Zoubkova et al. 2019). DArgic nuclei in the brain are known as A8, A9, and A10. The most significant are located in the substantia nigra pars compacta (A9) and medially in the VTA (A10). Fibers from the substantia nigra are projected into the striatum, and to a lesser extent into the globus pallidus (Schmidt et al. 1985, Albers and Sonsalla 1995, Williams and Goldman-Rakic 1995, Yui et al. 1996, Pendleton et al. 1998, Herlenius and Lagercrantz 2001, Kelley 2004, Ferrucci et al. 2019).

MA has been shown to produce ipsilateral circling behavior in rats. Treatment with D1 and 
D2 receptor agonists can induce contralateral circling. This indicates that circling results from an imbalance in DA transmission between the two hemispheres. $\sigma 1 \mathrm{R}$ activation appears to have a key role in MA's ability to increase DA signaling and related behaviors. MA enhance conditioned-learning and goal-oriented behavior through increased DA release during phasic DA firing, it is likely that drugs targeting $\sigma 1 \mathrm{R}$ may help reduce the reinforcing valence of MA (Hedges et al. 2018).

MA induces oxidative stress in neural tissue (Huang et al. 2013, Jang et al. 2017). Oxidative stress in DA terminals results from high levels of extravesicular DA that is then oxidized and metabolized and MA also inhibits complexes in the electron transport chain in the mitochondria. It is still unclear if there are other potential sources of oxidative stress in association with MA (Shiba et al. 2011). MA influences DA release through its prooxidant actions and downstream effects of resulting reactive oxygen species. Single dose of MA that leads to general DA depletion also induces formation of the free radical peroxynitrite, a reactive nitrogen species formed by the interaction between superoxide and nitric oxide. Furthermore, overexpressing a copper-zinc superoxide dismutase protects against both peroxynitrite formation as well as MA-induced DA depletion, indicating that superoxide is involved in MAs DA depleting effects (Albers and Sonsalla 1995, Boyson and Adams 1997, Fumagalli et al. 1998, Ferrucci et al. 2019). See Figure 2 for the illustration of oxidative stress reaction's role in MA induced toxicity.

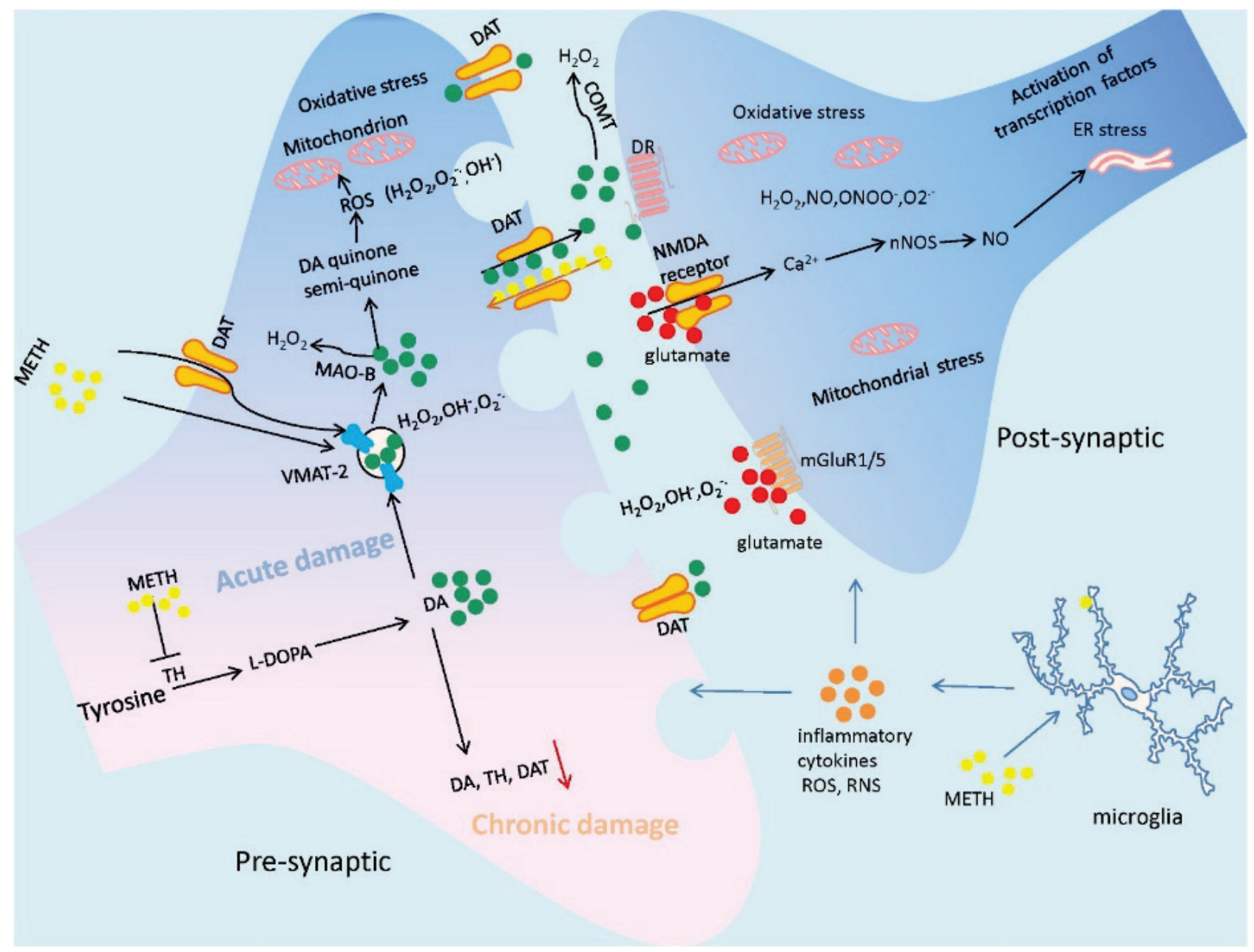

Fig. 2. Molecular mechanisms underlying MA induced neurotoxicity. Significant factors for cellular toxicity are oxidative stress reactions, including DA oxidation, excessive GLU production, generating a large amount of reactive oxygen species and reactive nitrogen species, leading to mitochondrial dysfunction. The neuroinflammation mediated by microglial cells also contribute to the neuronal damage by attacking it with inflammatory cytokines. As a result of the suffering from MA, the neuronal cells may undergo terminal degeneration or apoptosis. Due to the neurotoxicity of MA, chronic abuse of MA often causes the decrease of DArgic markers such as DA, tyrosine hydroxylase TH, DAT etc. Picture taken from Yang et al. (2018). 


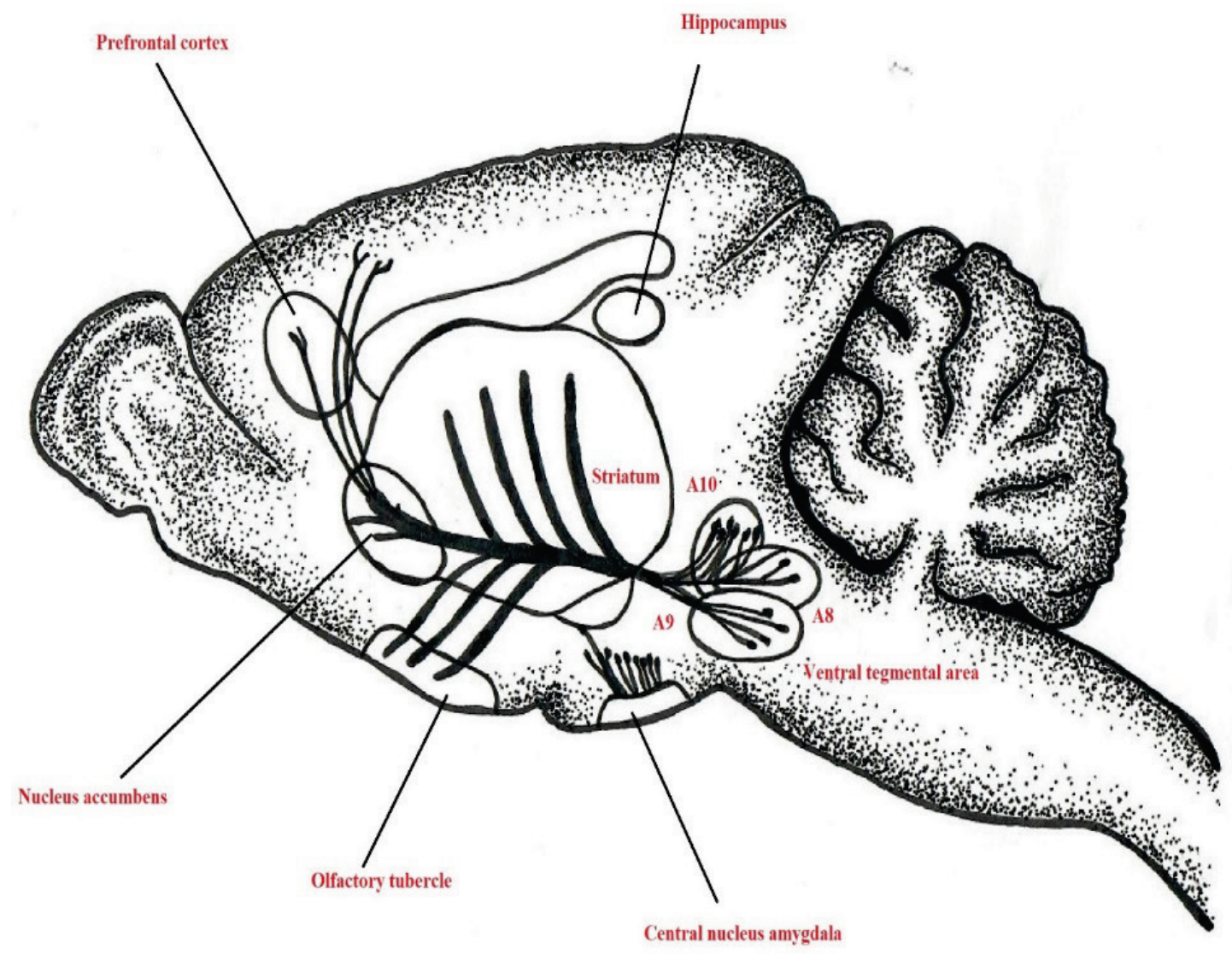

Fig. 3. Schematic diagram of anatomical regions of the reward pathway in a rat brain that is affected by MA. Most studies have investigated epigenetic changes in the nucleus accumbens that are induced by non-toxic doses of MA. Several of these investigations examined amphetamine-induced epigenetic changes in the striatum and hippocampus. Modified picture from Chiu and Schenk (2012).

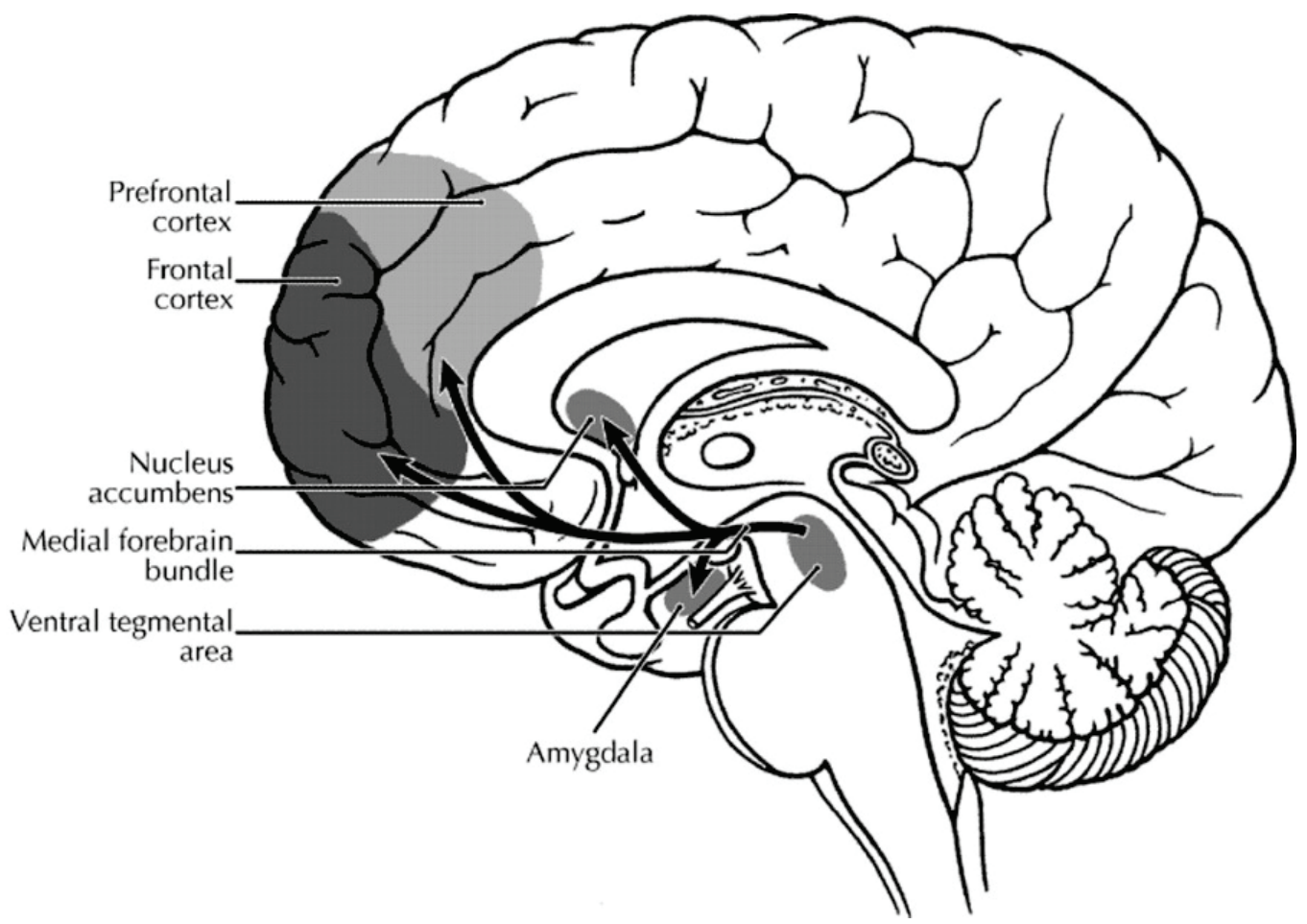

Fig. 4. Human brain areas mostly affected by MA. Prefrontal and frontal cortex contributes to planning and judgment, nucles accumbens, medial forebrain bundle and VTA are creating reward pathways and amygdala is responsible for projecting emotions. All these areas are widely affected by MA. This fact demonstrates behavioral and cognition changes in chronic MA users. Picture taken from Tomkins and Sellers (2001). 


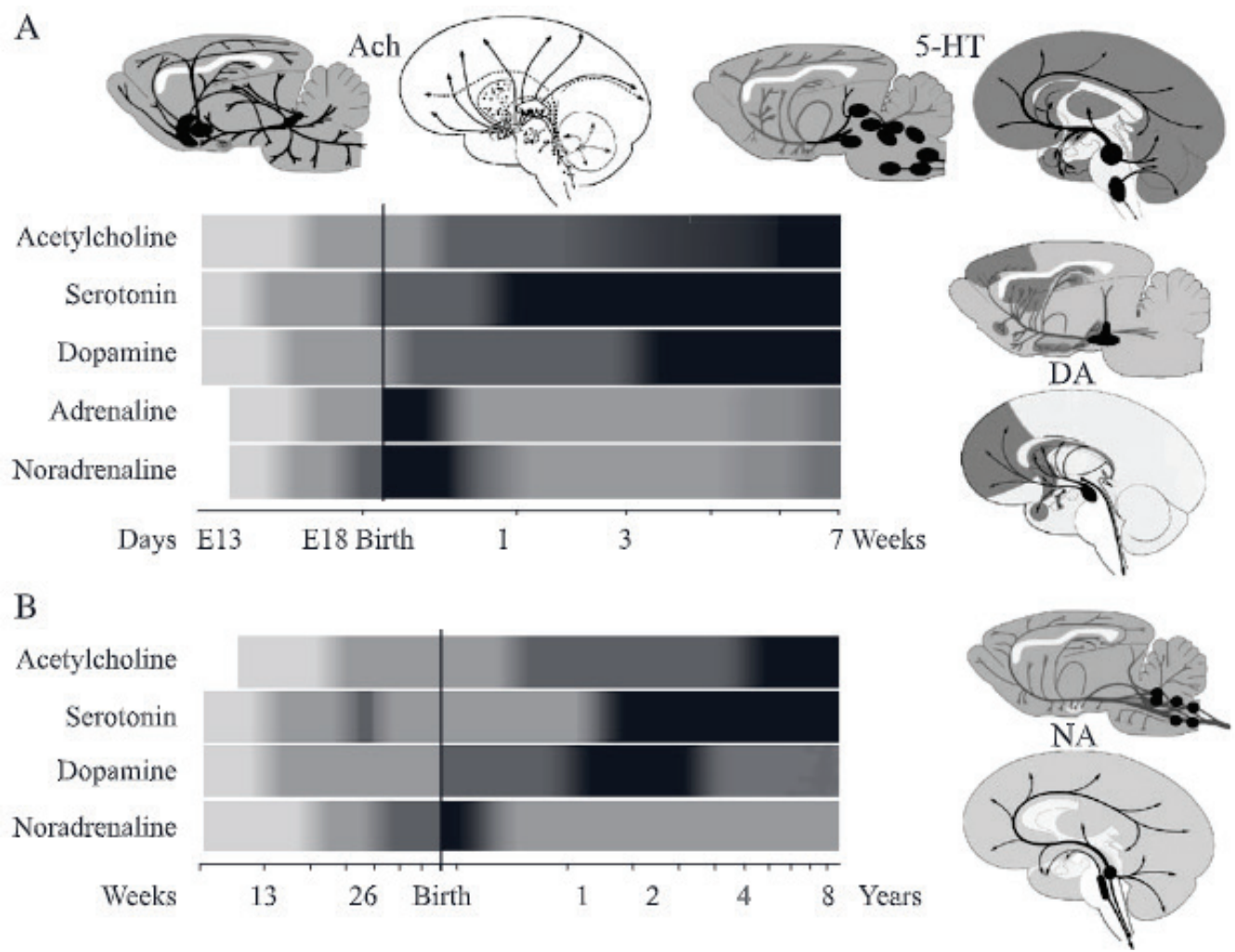

Fig. 5. Development of NEUs in human and rat brain. (A) This figure demonstrates development in rat brain representing in prenatal and postnatal days and (B) demonstrates development in human brain representing in prenatal and postnatal days. Bands represent illustrations of cell bodies and projections of monoamine NEUs systems. Picture taken from Herlenius et al. (2004).

Table 1. Protocols of MA treatment in laboratory rat experiments and their neurotoxic effects. Data taken from Yang et al. (2018).

\begin{tabular}{|c|c|c|c|}
\hline Animals & Dose & Effect & Source \\
\hline Rats & A single dose of $10 \mathrm{mg} / \mathrm{kg}$ i.p. & Neuroinflammation & Frank et al. 2016 \\
\hline Rats & $\begin{array}{l}0.001,0.03,0.1 \mathrm{mg} / \mathrm{kg} / \text { day } \\
\text { self-administration for three consecutive days }\end{array}$ & $\begin{array}{l}\text { Microglial activation, } \\
\text { neuroinflammation }\end{array}$ & Snider et al. 2013 \\
\hline Rats & 0.3 and $1.0 \mathrm{mg} / \mathrm{kg}$ i.v. for 2 weeks & MA addiction & Baumann et al. 2002 \\
\hline Rats & $2.5 \mathrm{mg} / \mathrm{kg}$ s.c., twice per day, for 7 days & $\begin{array}{l}\text { Decreased GABA, glutamate, } \\
\text { and glutamine levels in PFC }\end{array}$ & Hsieh et al. 2014 \\
\hline Rats & $5 \mathrm{mg} / \mathrm{kg}$ i.p. $\times 6$ at $1 \mathrm{~h}$ intervals & Dopamine depletion & Cadet et al. 2009 \\
\hline Rats & $10 \mathrm{mg} / \mathrm{kg}$ i.p. $\times 4$ at $2 \mathrm{~h}$ intervals & Mitochondrial dysfunction & $\begin{array}{l}\text { Burrows et al. } 2000 \text {, } \\
\text { Brown et al. } 2005\end{array}$ \\
\hline Rats & $10 \mathrm{mg} / \mathrm{kg}$ i.p. $\times 4$ at $2 \mathrm{~h}$ intervals & $\begin{array}{l}\text { Striatal ER and mitochondrial } \\
\text { stress pathways }\end{array}$ & Beauvais et al. 2011 \\
\hline Rats & $15 \mathrm{mg} / \mathrm{kg}$ i.p. $\times 8$ at $12 \mathrm{~h}$ intervals & $\begin{array}{l}\text { Hepatic injury, oxidative stress, } \\
\text { cell autophagy and apoptosis }\end{array}$ & Xie et al. 2018 \\
\hline Rats & $15 \mathrm{mg} / \mathrm{kg}$ i.p. $\times 4$ at $2 \mathrm{~h}$ intervals & Monoaminergic terminal loss & $\begin{array}{l}\text { LaVoie and Hastings } \\
\qquad 1999\end{array}$ \\
\hline Rats & $15 \mathrm{mg} / \mathrm{kg}$ i.p. $\times 8$ at $12 \mathrm{~h}$ intervals & $\begin{array}{l}\text { Neuronal apoptosis and } \\
\text { autophagy }\end{array}$ & Xu et al. 2017 \\
\hline Rats & $\begin{array}{l}\text { Repeated escalating doses: } 1-14 \mathrm{mg} / \mathrm{kg} \text { i.p. } \\
\text { twice a day at } 6 \mathrm{~h} \text { intervals, for } 14 \text { days }\end{array}$ & Dopaminergic neurons deficits & Valian et al. 2017 \\
\hline Rats & $\begin{array}{l}\text { Repeated escalating doses: } 1-10 \mathrm{mg} / \mathrm{kg} \text { i.p. } \\
\text { twice a day at } 5 \mathrm{~h} \text { intervals, for } 10 \text { days }\end{array}$ & Cognitive deficits & Beirami et al. 2018 \\
\hline
\end{tabular}


In the last few years, there are hypotheses about ubiquitin-proteasome system (UPS) disruption's contribution to alteration of DA neurotransmission. UPS is a major multi-catalytic machinery that's function is to ensure cellular proteostasis in eukaryotic cells. When UPS activity is impaired, early synaptic alterations occur. Similarly, psychiatric and behavioral disorders such as MA addiction and schizophrenia are associated with various UPS dysfunctions (Fornai et al. 1999, Shao and Zhu 2020, Darwin 2009, Breen et al. 2016).

MA, while being a powerful DA releaser also produces UPS inhibition. This fact indicates that DA transmission and UPS activity are connected to underlie behavioral control. UPS is deeply intermingled with the neurochemical and molecular events that may lead to behavioral alterations induced by the widely abused and highly addictive MA. This suggests that MA-induced inhibition of UPS may contribute to those plastic changes which lead to MA-induced addiction overlapping with psychiatric disorders (Nordahl et al. 2003, Breen et al. 2016). MA administration behavioral alterations are associated with some abnormalities of DA and GLU systems, which are similar to schizophrenia (Humbard and Maupin-Furlow 2013, Limanaqi et al. 2018, Ferrucci et al. 2019).

DA transmission, which is finely surveilled by the UPS, controls the presynaptic release of GLU via D1-like and D2-like receptors. This enhances GLU release that cannot be restrained since UPS is impaired. This receptor subtype is assumed as a key player in addiction due to the peculiar anatomy and synaptic localization. These receptors are involved in the modulation of GLU release by interacting with the GLU system, directly at the level of striatal excitatory asymmetrical synapses co-expressing DAT3, or indirectly, by regulating pyramidal GLU neurons through DAT1 in the prefrontal cortex. Link between UPS modulators and effects of DAT upon GLU release could provide new hypothesis of the molecular events which operate in addiction (Bennett et al. 2007, Alonso and Friedman 2013, Ferrucci et al. 2019).

\section{Serotonin and MA}

5-HTnergic neurons are localized in the midbrain, the substantia nigra, the hypothalamus, and the raphe nuclei of the brain stem. There exist a multitude of heterogeneous 5-HT receptors. The majority of the 5-HT receptors belong to the G-protein receptor family.
5-HT has been reported to affect neuronal proliferation, differentiation, migration, and synaptogenesis. It can already be detected in the fertilized egg and is involved in early morphogenesis of the heart, the craniofacial epithelia, and other structures. Serotoninergic cells appear $512^{\text {th }}$ gestational week in the human. These cells send axons to the forebrain and may be of importance in the differentiation of neuronal progenitors. Excess of 5-HT prevents the normal development of the somatosensory cortex. At birth, serotonergic-containing axons penetrate all cortical layers, but then decline markedly after about 3 weeks. Depletion of 5-HT after birth seems to have little effect on cortical development. Uptake and storage of 5-HT in developing thalamic neurons occur during formation of somatosensory cortex in mouse thanks to the temporary expression of the high affinity 5-HTT (Bar-Peled et al. 1991, Boutrel et al. 1999, Chugani 2002, Frankle et al. 2005).

Activation of the 5-HT1A receptor is associated with increased neurogenesis, neural differentiation, and dendritic maturation in the hippocampus. 5-HT concentration must be neither too high nor too low during the critical period of synaptogenesis and formation of brain connections. Miswiring problems due to excess or inadequate activation of specific 5-HT receptors during development may be involved in the genesis of psychiatric disorders such as anxiety disorders, drug addiction, and autism. 5-HT is transiently synthesized in high levels in young children (Schmidt et al. 1985, BarPeled et al. 1991, Kuczenski et al. 1995, Boutrel et al. 1999, Herlenius and Lagercrantz 2001, Hoyer et al. 2002, Chugani 2002, Verney et al. 2002, Gaspar et al. 2003).

The 5-HTergic system in the CNS has a regulatory effect on many functions and modulates the activity of other projection systems. This system is closely linked to the NA system that is often supplementing it. The effect of 5-HT is strongly dependent on the receptors expressed on the neurons of any given structure. The soma of most neurons in this system are in the raphe nuclei of the reticular formation. Their axons enter both ascending and descending tracts, reaching all cortical areas as prefrontal cortex and all limbic system structures such as the hippocampus, with others reaching the striatum, thalamus, hypothalamus, brain stem, cerebellum, and spinal cord. Excessive activity in ascending tracts leads to mood changes and behavior disorders. Reductions in forebrain concentrations 5-HT and its metabolites and a decrease of tryptophan hydroxylase activity after MA administration 
have been described. In general, we can say that MA causes reduced level of 5-HT mainly in striatum, but also in hippocampus. Mechanism of lowering 5-HT levels by MA is not still clear. MA associated reduction in 5-HTT function may be caused by several factors including hyperthermia, which contributes to the long-term DAergic and 5-HTergic neurochemical changes caused by MA. This happens possibly by promoting the formation of reactive oxygen species. MA caused hyperthermia, can be lethal. Dissociation between 5-HT uptake and ligand binding could be due to a change in transporter phosphorylation state and/or cell surface expression of transporter protein. It is also possible that MA treatment alters transporter regulation processes causing transporter internalization to occur, which in turn would result in a decrease in transporter function with no change in ligand binding. Lowered 5-HT synthesis causes depression and sleep disorders (Schmidt et al. 1985, Heikkila et al. 1988, Fumagalli et al. 1998, Imam et al. 2001, Chugani 2002, Gaspar et al. 2003, Frankle et al. 2005, Riddle et al. 2006, Fleckenstein et al. 2009).

\section{Conclusions}

This review provided a summary of current knowledge about role of NEUs alteration in MA-induced neurotoxicity. However, there are still huge gaps in this area of scientific research that need to be filled with further research.

\section{Conflict of Interest}

There is no conflict of interest.

\section{Acknowledgements}

This work was supported by research program PROGRES Q 35, and student projects GAUK 1442120 and 260533/SVV/2021 from Charles University, and project PharmaBrain CZ.02.1.01/0.0/0.0/16_025/0007444 funded from OP VVV.

\section{References}

AGGARWAL S, MORTENSEN OV: Overview of monoamine transporters. Curr Protoc Pharmacol 79: 12.16.1-12.16.17, 2017. https://doi.org/10.1002/cpph.32

ALBERS DS, SONSALLA PK: Methamphetamine-induced hyperthermia and dopaminergic neurotoxicity in mice: pharmacological profile of protective and nonprotective agents. J Pharmacol Exp Ther 275: 1104-1114, 1995.

ALI SF, KORDSMEIER KJ, GOUGH B: Drug-induced circling preference in rats. Correlation with monoamine levels. Mol Neurobiol 11: 145-154, 1995. https://doi.org/10.1007/BF02740691

ALONSO V, FRIEDMAN PA: Minireview: ubiquitination-regulated G protein-coupled receptor signaling and trafficking. Mol Endocrinol 27: 558-572, 2013. https://doi.org/10.1210/me.2012-1404

ANGLIN MD, BURKE C, PERROCHET B, STAMPER E, DAWUD-NOURSI S: History of the methamphetamine problem. J Psychoactive Drugs 32: 137-141, 2000. https://doi.org/10.1080/02791072.2000.10400221

BAR-PELED O, GROSS-ISSEROFF R, BEN-HUR H, HOSKINS I, GRONER Y, BIEGON A: Fetal human brain exhibits a prenatal peak in the density of serotonin 5-HT1A receptors. Neurosci Lett 127: 173-176, 1991. https://doi.org/10.1016/0304-3940(91)90787-T

BENNETT EJ, SHALER TA, WOODMAN B, RYU KY, ZAITSEVA TS, BECKER CH, BATES GP, SCHULMAN H, KOPITO RR: Global changes to the ubiquitin system in Huntington's disease. Nature 448: 704-708, 2007. https://doi.org/10.1038/nature06022

BOUTREL B, FRANC B, HEN R, HAMON M, ADRIEN J: Key role of 5-HT1B receptors in the regulation of paradoxical sleep as evidenced in 5-HT1B knock-out mice. J Neurosci 19: 3204-3212, 1999. https://doi.org/10.1523/JNEUROSCI.19-08-03204.1999

BOYSON SJ, ADAMS CE: D1 and D2 dopamine receptors in perinatal and adult basal ganglia. Pediatr Res 41: 822-831, 1997. https://doi.org/10.1203/00006450-199706000-00006

BREEN MS, UHLMANN A, NDAY CM, GLATT SJ, MITT M, METSALPU A, STEIN DJ, ILLING N: Candidate gene networks and blood biomarkers of methamphetamine-associated psychosis: an integrative RNA-sequencing report. Transl Psychiatry 6: e802, 2016. https://doi.org/10.1038/tp.2016.67 
CALIPARI ES, BAGOT RC, PURUSHOTHAMAN I, DAVIDSON TJ, YORGASON JT, PENA CJ, WALKER DM, PIRPINIAS ST, GUISE KG, RAMAKRISHNAN C, DEISSEROTH K, NESTLER EJ: In vivo imaging identifies temporal signature of D1 and D2 medium spiny neurons in cocaine reward. Proc Natl Acad Sci U S A 113: 2726-2731, 2016. https://doi.org/10.1073/pnas.1521238113

CALIPARI ES, JUAREZ B, MOREL C, WALKER DM, CAHILL ME, RIBEIRO E, ROMAN-ORTIZ C, RAMAKRISHNAN C, DEISSEROTH K, HAN MH, NESTLER EJ: Dopaminergic dynamics underlying sex-specific cocaine reward. Nat Commun 8: 13877, 2017. https://doi.org/10.1038/ncomms13877

CHEBIB M, JOHNSTON GA: The 'ABC' of GABA receptors: a brief review. Clin Exp Pharmacol Physiol 26: 937-940, 1999. https://doi.org/10.1046/j.1440-1681.1999.03151.x

CHEBIB M, JOHNSTON GA: GABA-activated ligand gated ion channels: medicinal chemistry and molecular biology. J Med Chem 43: 1427-1447, 2000. https://doi.org/10.1021/jm9904349

CHEBIB M, MEWETT KN, JOHNSTON GA: GABA(C) receptor antagonists differentiate between human rho1 and rho2 receptors expressed in Xenopus oocytes. Eur J Pharmacol 357: 227-234, 1998. https://doi.org/10.1016/S00142999(98)00552-4

CHIU VM, SCHENK JO: Mechanism of action of methamphetamine within the catecholamine and serotonin areas of the central nervous system. Curr Drug Abuse Rev 5: 227-242, 2012. https://doi.org/10.2174/1874473711205030227

CHUGANI DC: Role of altered brain serotonin mechanisms in autism. Mol Psychiatry 7 (Suppl 2): S16-S17, 2002. https://doi.org/10.1038/sj.mp. 4001167

DARWIN KH: Prokaryotic ubiquitin-like protein (Pup), proteasomes and pathogenesis. Nat Rev Microbiol 7: 485-491, 2009. https://doi.org/10.1038/nrmicro2148

DIAMOND A: Evidence for the importance of dopamine for prefrontal cortex functions early in life. Philos Trans R Soc Lond B Biol Sci 351: 1483-1493; discussion 1494, 1996. https://doi.org/10.1098/rstb.1996.0134

DIAMOND A, BRIAND L, FOSSELLA J, GEHLBACH L: Genetic and neurochemical modulation of prefrontal cognitive functions in children. Am J Psychiatry 161: 125-132, 2004. https://doi.org/10.1176/appi.ajp.161.1.125

DINOPOULOS A, PARNAVELAS JG: The development of ventral tegmental area (VTA) projections to the visual cortex of the rat. Neurosci Lett 134: 12-16, 1991. https://doi.org/10.1016/0304-3940(91)90497-H

FERRUCCI M, LIMANAQI F, RYSKALIN L, BIAGIONI F, BUSCETI CL, FORNAI F: The effects of amphetamine and methamphetamine on the release of norepinephrine, dopamine and acetylcholine from the brainstem reticular formation. Front Neuroanat 13: 48, 2019. https://doi.org/10.3389/fnana.2019.00048

FLECKENSTEIN AE, VOLZ TJ, HANSON GR: Psychostimulant-induced alterations in vesicular monoamine transporter-2 function: neurotoxic and therapeutic implications. Neuropharmacology 56 (Suppl 1): 133-138, 2009. https://doi.org/10.1016/j.neuropharm.2008.07.002

FORNAI F, GIORGI FS, ALESSANDRI MG, GIUSIANI M, CORSINI GU: Effects of pretreatment with $\mathrm{N}$-(2-chloroethyl)-N-ethyl-2-bromobenzylamine (DSP-4) on methamphetamine pharmacokinetics and striatal dopamine losses. J Neurochem 72: 777-784, 1999. https://doi.org/10.1046/j.1471-4159.1999.0720777.x

FRANKLE WG, LOMBARDO I, NEW AS, GOODMAN M, TALBOT PS, HUANG Y, HWANG D-R, SLIFSTEIN M, CURRY S, ABI-DARGHAM A, LARUELLE M, SIEVER LJ: Brain serotonin transporter distribution in subjects with impulsive aggressivity: a positron emission study with [11C]McN 5652. Am J Psychiatry 162: 915-923, 2005. https://doi.org/10.1176/appi.ajp.162.5.915

FUMAGALLI F, GAINETDINOV RR, VALENZANO KJ, CARON MG: Role of dopamine transporter in methamphetamine-induced neurotoxicity: evidence from mice lacking the transporter. J Neurosci 18: 4861-4869, 1998. https://doi.org/10.1523/JNEUROSCI.18-13-04861.1998

GASPAR P, CASES O, MAROTEAUX L: The developmental role of serotonin: news from mouse molecular genetics. Nat Rev Neurosci 4: 1002-1012, 2003. https://doi.org/10.1038/nrn1256

GOLDSTEIN DS: Catecholamines in the periphery. Overview. Adv Pharmacol 42: 529-539, 1998. https://doi.org/10.1016/S1054-3589(08)60806-6

GRELLA CE, ANGLIN MD: Introduction to the special issue on addiction health services: in memory of Douglas Longshore. J Behav Health Serv Res 36: 131-136, 2009. https://doi.org/10.1007/s11414-008-9157-8

GUPTA S, KULHARA P: Cellular and molecular mechanisms of drug dependence: An overview and update. Indian J Psychiatry 49: 85-90, 2007. https://doi.org/10.4103/0019-5545.33253 
HAPPE HK, COULTER CL, GERETY ME, SANDERS JD, O'ROURKE M, BYLUND DB, MURRIN LC: Alpha-2 adrenergic receptor development in rat CNS: an autoradiographic study. Neuroscience 123: 167-178, 2004. https://doi.org/10.1016/j.neuroscience.2003.09.004

HART CL, MARVIN CB, SILVER R, SMITH EE: Is cognitive functioning impaired in methamphetamine users? A critical review. Neuropsychopharmacology 37: 586-608, 2012. https://doi.org/10.1038/npp.2011.276

HEDGES DJ, HAMILTON-NELSON KL, SACHAROW SJ, NATIONS L, BEECHAM GW, KOZHEKBAEVA ZM, BUTLER BL, CUKIER HN, WHITEHEAD PL, MA D, JAWORSKI JM, NATHANSON L, LEE JM, HAUSER SL, OKSENBERG JR, CUCCARO ML, HAINES JL, GILBERT JR, PERICAK-VANCE MA: Evidence of novel fine-scale structural variation at autism spectrum disorder candidate loci. Mol Autism 3: 2, 2012. https://doi.org/10.1186/2040-2392-3-2

HEDGES DM, OBRAY JD, YORGASON JT, JANG EY, WEERASEKARA VK, UYS JD, BELLINGER FP, STEFFENSEN SC: Methamphetamine induces dopamine release in the nucleus accumbens through a sigma receptor-mediated pathway. Neuropsychopharmacology 43: 1405-1414, 2018. https://doi.org/10.1038/npp.2017.291

HEIKKILA RE, YOUNGSTER SK, PANEK DU, GIOVANNI A, SONSALLA PK: Studies with the neurotoxicant 1-methyl-4-phenyl-1,2,3,6-tetrahydropyridine (MPTP) and several of its analogs. Toxicology 49: 493-501, 1988. https://doi.org/10.1016/0300-483X(88)90035-2

HERLENIUS E, LAGERCRANTZ H: Neurotransmitters and neuromodulators during early human development. Early Hum Dev 65: 21-37, 2001. https://doi.org/10.1016/S0378-3782(01)00189-X

HERLENIUS E, LAGERCRANTZ H: Development of neurotransmitter systems during critical periods. Exp Neurol 190 (Suppl 1): S8-S21, 2004. https://doi.org/10.1016/j.expneurol.2004.03.027

HOYER D, HANNON JP, MARTIN GR: Molecular, pharmacological and functional diversity of 5-HT receptors. Pharmacol Biochem Behav 71: 533-554, 2002. https://doi.org/10.1016/S0091-3057(01)00746-8

HSIEH JH, STEIN DJ, HOWELLS FM: The neurobiology of methamphetamine induced psychosis. Front Hum Neurosci 8: 537, 2014. https://doi.org/10.3389/fnhum.2014.00537

HUANG MC, LIN SK, CHEN CH, PAN CH, LEE CH, LIU HC: Oxidative stress status in recently abstinent methamphetamine abusers. Psychiatry Clin Neurosci 67: 92-100, 2013. https://doi.org/10.1111/pcn.12025

HUMBARD MA, MAUPIN-FURLOW JA: Prokaryotic proteasomes: nanocompartments of degradation. J Mol Microbiol Biotechnol 23: 321-334, 2013. https://doi.org/10.1159/000351348

IMAM SZ, EL-YAZAL J, NEWPORT GD, ITZHAK Y, CADET JL, SLIKKER W JR, ALI SF: Methamphetamineinduced dopaminergic neurotoxicity: role of peroxynitrite and neuroprotective role of antioxidants and peroxynitrite decomposition catalysts. Ann N Y Acad Sci 939: 366-380, 2001. https://doi.org/10.1111/j.17496632.2001.tb03646.x

JANG EY, YANG CH, HEDGES DM, KIM SP, LEE JY, EKINS TG, GARCIA BT, KIM HY, NELSON AC, KIM NJ, STEFFENSEN SC: The role of reactive oxygen species in methamphetamine self-administration and dopamine release in the nucleus accumbens. Addict Biol 22: 1304-1315, 2017. https://doi.org/10.1111/adb.12419

KELLEY AE: Memory and addiction: shared neural circuitry and molecular mechanisms. Neuron 44: 161-179, 2004. https://doi.org/10.1016/j.neuron.2004.09.016

KOOB GF, LE MOAL M: Drug addiction, dysregulation of reward, and allostasis. Neuropsychopharmacology 24: 97-129, 2001. https://doi.org/10.1016/S0893-133X(00)00195-0

KUCZENSKI R, SEGAL DS, CHO AK, MELEGA W: Hippocampus norepinephrine, caudate dopamine and serotonin, and behavioral responses to the stereoisomers of amphetamine and methamphetamine. J Neurosci 15: 1308-1317, 1995. https://doi.org/10.1523/JNEUROSCI.15-02-01308.1995

LAGALI PS, CORCORAN CP, PICKETTS DJ: Hippocampus development and function: role of epigenetic factors and implications for cognitive disease. Clin Genet 78: 321-333, 2010. https://doi.org/10.1111/j.1399-0004.2010.01503.x

LIMANAQI F, GAMBARDELLA S, BIAGIONI F, BUSCETI CL, FORNAI F: Epigenetic effects induced by methamphetamine and methamphetamine-dependent oxidative stress. Oxid Med Cell Longev 2018: 4982453, 2018. https://doi.org/10.1155/2018/4982453

MACUCHOVA E, SLAMBEROVA R: Drug sensitization induced by prenatal methamphetamine exposure. (Article in English, Czech) Cesk Fysiol 65: 32-37, 2016. 
MARK KA, SOGHOMONIAN JJ, YAMAMOTO BK: High-dose methamphetamine acutely activates the striatonigral pathway to increase striatal glutamate and mediate long-term dopamine toxicity. J Neurosci 24: 11449-11456, 2004. https://doi.org/10.1523/JNEUROSCI.3597-04.2004

MELDRUM BS: Glutamate as a neurotransmitter in the brain: review of physiology and pathology. J Nutr 130 (4S Suppl): 1007S-1015S, 2000. https://doi.org/10.1093/jn/130.4.1007S

MEYERS SA, RAFFUL C, MITTAL ML, SMITH LR, TIRADO-MUNOZ J, JAIN S, SUN X, GARFEIN RS, STRATHDEE SA, DEBECK K, HAYASHI K, MCNEIL R, MILLOY MJ, OLDING M, GUISE A, WERB D, SCHEIM AI: Examining the gender composition of drug injecting initiation events: A mixed methods investigation of three North American contexts. Int J Drug Policy 90: 103056, 2021. https://doi.org/10.1016/j.drugpo.2020.103056

NAQUI SZ, HARRIS BS, THOMAIDOU D, PARNAVELAS JG: The noradrenergic system influences the fate of Cajal-Retzius cells in the developing cerebral cortex. Brain Res Dev Brain Res 113: 75-82, 1999. https://doi.org/10.1016/S0165-3806(99)00003-6

NORDAHL TE, SALO R, LEAMON M: Neuropsychological effects of chronic methamphetamine use on neurotransmitters and cognition: A review. J Neuropsychiatry Clin Neurosci 15: 317-325, 2003. https://doi.org/10.1176/jnp.15.3.317

OLSON L, SEIGER A: Early prenatal ontogeny of central monoamine neurons in the rat: fluorescence histochemical observations. Z Anat Entwicklungsgesch 137: 301-316, 1972. https://doi.org/10.1007/BF00519099

PENDLETON RG, RASHEED A, ROYCHOWDHURY R, HILLMAN R: A new role for catecholamines: ontogenesis. Trends Pharmacol Sci 19: 248-251, 1998. https://doi.org/10.1016/s0165-6147(98)01218-8

PEREIRA FC, ROLO MR, MARQUES E, MENDES VM, RIBEIRO CF, ALI SF, MORGADINHO T, MACEDO TR: Acute increase of the glutamate-glutamine cycling in discrete brain areas after administration of a single dose of amphetamine. Ann N Y Acad Sci 1139: 212-221, 2008. https://doi.org/10.1196/annals.1432.040

RIDDLE EL, FLECKENSTEIN AE, HANSON GR: Mechanisms of methamphetamine-induced dopaminergic neurotoxicity. AAPS J 8: E413-E418, 2006. https://doi.org/10.1007/BF02854914

SHAO X, ZHU G: Associations among monoamine neurotransmitter pathways, personality traits, and major depressive disorder. Front Psychiatry 11: 381, 2020. https://doi.org/10.3389/fpsyt.2020.00381

SHIBA T, YAMATO M, KUDO W, WATANABE T, UTSUMI H, YAMADA K: In vivo imaging of mitochondrial function in methamphetamine-treated rats. Neuroimage 57: 866-872, 2011. https://doi.org/10.1016/j.neuroimage.2011.05.041

SCHMIDT CJ, RITTER JK, SONSALLA PK, HANSON GR, GIBB JW: Role of dopamine in the neurotoxic effects of methamphetamine. J Pharmacol Exp Ther 233: 539-544, 1985.

SCHMIDT CJ, SONSALLA PK, HANSON GR, PEAT MA, GIBB JW: Methamphetamine-induced depression of monoamine synthesis in the rat: development of tolerance. J Neurochem 44: 852-855, 1985. https://doi.org/10.1111/j.1471-4159.1985.tb12893.x

SLAMBEROVA R: Review of long-term consequences of maternal methamphetamine exposure. Physiol Res 68 (Suppl 3): S219-S231, 2019. https://doi.org/10.33549/physiolres.934360

STEPHANS SE, YAMAMOTO BK: Methamphetamine-induced neurotoxicity: roles for glutamate and dopamine efflux. Synapse 17: 203-209, 1994. https://doi.org/10.1002/syn.890170310

SULZER D, SONDERS MS, POULSEN NW, GALLI A: Mechanisms of neurotransmitter release by amphetamines: A review. Prog Neurobiol 75: 406-433, 2005. https://doi.org/10.1016/j.pneurobio.2005.04.003

SZUMLINSKI KK, LOMINAC KD, CAMPBELL RR, COHEN M, FULTZ EK, BROWN CN, MILLER BW, QUADIR SG, MARTIN D, THOMPSON AB, VON JONQUIERES G, KLUGMANN M, PHILLIPS TJ, KIPPIN TE: Methamphetamine addiction vulnerability: the glutamate, the bad, and the ugly. Biol Psychiatry 81: 959-970, 2017. https://doi.org/10.1016/j.biopsych.2016.10.005

TAKADA M, HATTORI T: Organization of ventral tegmental area cells projecting to the occipital cortex and forebrain in the rat. Brain Res 418: 27-33, 1987. https://doi.org/10.1016/0006-8993(87)90958-9

TOMÁŠKOVÁ A, ŠLAMBEROVÁ R, ČERNÁ M: Influence of prenatal methamphetamine abuse on the brain. Epigenomes 4: 14, 2020. https://doi.org/10.3390/epigenomes4030014

TOMKINS DM, SELLERS EM: Addiction and the brain: the role of neurotransmitters in the cause and treatment of drug dependence. CMAJ 164: 817-821, 2001. 
VERNEY C, LEBRAND C, GASPAR P: Changing distribution of monoaminergic markers in the developing human cerebral cortex with special emphasis on the serotonin transporter. Anat Rec 267: 87-93, 2002. https://doi.org/10.1002/ar.10089

VRAJOVA M, SLAMBEROVA R, HOSCHL C, OVSEPIAN SV: Methamphetamine and sleep impairments: neurobehavioral correlates and molecular mechanisms. Sleep 44: zsab001, 2021. https://doi.org/10.1093/sleep/zsab001

WEARNE TA, CORNISH JL: Inhibitory regulation of the prefrontal cortex following behavioral sensitization to amphetamine and/or methamphetamine psychostimulants: A review of GABAergic mechanisms. Prog Neuropsychopharmacol Biol Psychiatry 95: 109681, 2019. https://doi.org/10.1016/j.pnpbp.2019.109681

WILLIAMS GV, GOLDMAN-RAKIC PS: Modulation of memory fields by dopamine D1 receptors in prefrontal cortex. Nature 376: 572-575, 1995. https://doi.org/10.1038/376572a0

YUI K, GOTO K, IKEMOTO S, ISHIGURO T: Monoamine neurotransmitter function and spontaneous recurrence of methamphetamine psychosis. Ann N Y Acad Sci 801: 415-429, 1996. https://doi.org/10.1111/j.17496632.1996.tb17464.x

ZHOU QY, PALMITER RD: Dopamine-deficient mice are severely hypoactive, adipsic, and aphagic. Cell 83: 1197-1209, 1995. https://doi.org/10.1016/0092-8674(95)90145-0

ZOUBKOVA H, TOMASKOVA A, NOHEJlOVA K, CERNA M, SLAMBEROVA R: Prenatal exposure to methamphetamine: Up-regulation of brain receptor genes. Front Neurosci 13: 771, 2019. https://doi.org/10.3389/fnins.2019.00771 